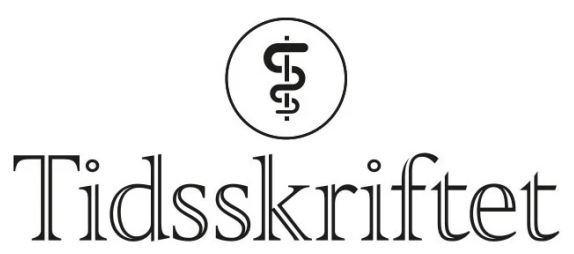

DEN NORSKE LEGEFORENING

\title{
Mutanten er løs
}

\author{
FRA REDAKTØREN
}

\section{LISE SKOGSTAD LOFTSGAARD}

lise.skogstad.loftsgaard@tidsskriftet.no

Lise Skogstad Loftsgaard er lege og medisinsk redaktør i Tidsskriftet.

\section{Koronaviruset har mutert. Norge frykter mutanten. Hvor mange nordmenn vet at mutasjon egentlig bare betyr forandring?}

Foto: privat

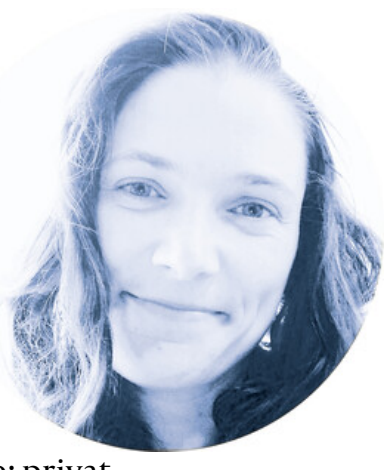

«Koronaviruset setter oss alle på prøve», sa statsminister Erna Solberg på en pressekonferanse 10. mars 2020 (1). Siden har departementene holdt 161 pressekonferanser om covid-19, og smittevernforskriften er blitt endret mer enn 70 ganger $(\underline{2}, 3)$. For at smitteverntiltak skal ha effekt, er vi avhengige av god etterlevelse. Da er det nødvendig at alle forstår, har tiltro til beslutningstakerne og opplever tillit til kunnskapen som formidles.

Verdens helseorganisasjon var tidlig ute og advarte mot en infodemi - den overfloden av informasjon som utløses under en epidemi. (4.). Infodemier kan føre til mistillit til myndighetene og til iverksatte folkehelsetiltak: «Rett beskjed til rett tid fra den rette budbringeren i det rette mediet kan redde liv-feilinformasjon eller uklare beskjeder kan koste liv» (4).) (egen oversettelse).

I en spørreundersøkelse blant rundt 700 personer i Sveits i slutten av mars 2020 undersøkte man om valg av budbringer påvirket etterlevelse av sosiale distanseringstiltak (5), og en myndighetsrepresentant ble sammenliknet med en person fra kultureliten. Deltakerne ble spurt om sin støtte til tiltakene, i hvor stor grad de etterfulgte dem på det aktuelle tidspunktet og hvordan de vurderte egen antatt etterlevelse frem i tid. Myndighetenes 
representant var assosiert med høyere etterlevelse av tiltak i øyeblikket, men påvirket ikke antatt fremtidig etterlevelse. Dette kan tale for at ikke bare budbringeren, men også rett beskjed til rett tid er viktig, og at gjentatt formidling kan være nødvendig for å unngå tiltakstretthet.

I arbeid med kommunikasjonsstrategier under kriser må man ta høyde for tre hovedutfordringer: for mye informasjon, usikker informasjon og feilinformasjon. Etter pandemiens første bølge skrev Vraga og Jacobsen at disse utfordringene kan motvirkes ved flere tiltak (ㅁ).

\section{«Både myndigheter, forskere, klinikere og presse har et ansvar for at vi ikke også får en kunnskapsmutasjon»}

Et av tiltakene er å målrette informasjon til særlige grupper. Dette var man tidlig oppmerksom på i Norge, og det er laget anbefalinger for hvordan man bør møte grupper som kan være vanskelige å nå, enten det skyldes manglende språk-, helse- eller situasjonsforståelse eller andre faktorer som gjør at man står utenfor storsamfunnet i livsanskuelse eller livsførsel (7.). Ifølge Folkehelseinstituttet bør tillitsbygging og dialog defineres som hovedstrategi. Informasjon på ulike morsmål er lett å finne hvis man forstår norsk, men hvordan man i praksis skal få informasjonen ut til gruppene, er ikke åpenbart. Lokalt helsevesen oppfordres til å benytte ulike organisasjoner, tolketjenester og lokale ressurspersoner i miljøene. I tillegg har flere frivillige organisasjoner mottatt støtte til informasjonstiltak i innvandrerbefolkningen ( $\underline{8})$. Likevel er status etter nesten ett år med pandemi at omtrent halvparten av de bekreftet smittede i Norge er innvandrere og deres $\operatorname{barn}(9$.$) .$

Direkte feilinformasjon tilslører budskapet (ㅁ), men også sensasjonspreget journalistikk og klikkåter kan være villedende. Balansen mellom å fremme (sikker og tydelig kunnskap) og å skremme kan være vanskelig - særlig i større grupper der det er stor variasjon i forutsetningene for å forstå informasjon og å oppsøke den.

Mediemangfoldsregnskapet 2020 viser at koronapandemien har påvirket hvor vi søker informasjon (10). Etter nedstengingen i mars $2020 \emptyset$ kte bruken av redaktørstyrte medier umiddelbart. Det totale nyhetskonsumet $\emptyset \mathrm{kte}$, og samtidig falt andelen som oppgav sosiale medier som sin viktigste nyhetskilde fra $26 \%$ i 2019 til $18 \%$ i 2020. Yngre, kvinner, de med lav utdanning og de med lav inntekt orienterer seg i mindre grad mot redaktørstyrte medier. Dette kan skape store informasjonskløfter.

Å spre mye informasjon om et spesialisert tema til en hel befolkning er en spenstig øvelse som krever oversettelse av faguttrykk til et språk som er tilgjengelig for flere. Da er beskrivelser som «britisk skrekkvariant» (1ㅡ) og “Virusmutant herjer: - En skrekkfilm» (1ㅡ). åpenbart ikke hensiktsmessige. I en stor informasjonsmengde må budskapet være tydelig og tilgjengelig. Og det ser ut til at nordmenn flest har forstått alvoret. Ni av ti nordmenn angir nå at de bruker munnbind og holder avstand (13).

Koronaviruset muterer kontinuerlig og nye varianter oppstår. Både myndigheter, forskere, klinikere og presse har et ansvar for at vi ikke også får en kunnskapsmutasjon som gjør at mottakeren sitter igjen med en variant som er farligere.

\section{LITTERATUR}

1. Regjeringen. Koronasituasjonen: Statsministeren og finansministeren orienterer om tiltak knytta til koronaviruset. https://www.regjeringen.no/no/aktuelt/statsministeren-og-finansministerenorienterer-om-tiltak-knytta-til-koronaviruset/id2693004/ Lest 10.2.2021.

2. Regjeringen.no. Pressekonferanser og andre nett-tv-sendinger.

https://www.regjeringen.no/no/aktuelt/nett-tv/id2000007/?topic=2692388\&term= Lest 9.2.2021. 
3. Johansen PA, Røed-Johansen D, Murray SM et al. 73 ganger har regjeringen endret smitteforskriften. Men vet vi hva som egentlig har virket? Aftenposten 18.1.2021.

https://www.aftenposten.no/norge/i/zgo3X5/73-ganger-har-regjeringen-endret-smitteforskriften-vetvi-hva-som-ege Lest 6.2.2021.

4. World Health Organization. Infodemic management. https://www.who.int/teams/riskcommunication/infodemic-management Lest 29.1.2021.

5. Abu-Akel A, Spitz A, West R. Who is listening? Spokesperson effect on communicating social and physical distancing measures during the COVID-19 pandemic. Front Psychol 2021; 11: 564434. [PubMed][CrossRef]

6. Vraga EK, Jacobsen KH. Strategies for effective health communication during the coronavirus pandemic and future emerging infectious disease events. World Med Health Policy 2020; 12: 233-41. [CrossRef]

7. Folkehelseinstituttet. Kommunikasjon med minoritets- og innvandrermiljøer, og andre grupper som kan være vanskelig å nå.

https://www.fhi.no/nettpub/coronavirus/infomateriell/kommunikasjon-med-grupper-som-kan-varevanskelig-a-na/ Lest 6.2.2021.

8. Regjeringen. Styrker koronainformasjonen til innvandrergrupper.

https://www.regjeringen.no/no/aktuelt/styrker-korona-informasjonen-til-

innvandrergrupper/id2696718/ Lest 9.2.2021.

9. Stokke O, Johansen PA. Nye FHI-tall: Nesten halvparten av smitten har skjedd i innvandrermiljøer. Aftenposten 3.2.2021. https://www.aftenposten.no/norge/i/869KzG/pandemien-har-rammet-norskeinnvandrermiljoeer-hardere-enn-noen-har-vis Lest 6.2.2021.

10. Mediemangfoldsregnskapet 2020. Fredrikstad: Medietilsynet, 2021.

https://www.medietilsynet.no/globalassets/publikasjoner/2020/mediemangfoldsregnskapet2020/210129-mediemangfold_bruksperspektiv_2021.pdf Lest 7.2.2021.

11. Lerø M. Hestekur mot britisk skrekkvariant. Dagens perspektiv 25.1.2021.

https://www.dagensperspektiv.no/leder/2021/hestekur-mot-britisk-skrekkvariant Lest 29.1.2021.

12. Hagen A. Virusmutant herjer: - En skrekkfilm. Dagbladet 29.1.2021.

https://www.dagbladet.no/nyheter/virusmutant-herjer---en-skrekkfilm/73342488 Lest 6.2.2021.

13. Opinion. Hele Norge har munnbind. https://opinion.no/2021/o2/hele-norge-har-munnbind/ Lest 9.2.2021.

Publisert: 22. februar 2021. Tidsskr Nor Legeforen. DOI:10.4045/tidsskr.21.0112

(C) Tidsskrift for Den norske legeforening 2023. Lastet ned fra tidsskriftet.no 26. april 2023. 